\title{
COMPARISON OF THE CLEANING EFFICACY OF THE FKG RACE SYSTEM AND HAND INSTRUMENT IN MOLAR ROOT CANAL
}

\author{
COMPARAÇÃO DA EFICÁCIA DE LIMPEZA ENTRE O SISTEMA FKG \\ RACE E INSTRUMENTOS MANUAIS EM MOLARES INFERIORES
}

Carla Renata SIPERT ${ }^{1}$, Renata Pardini HUSSNE², Celso Kenji NISHIYAMA ${ }^{3}$

\begin{abstract}
1- DDS, Specialist in Endodontics - Hospital de Reabilitação de Anomalias Craniofaciais - USP, Bauru, SP, Brazil.
2- DDS, PhD Student in Endodontics(UNESP - Araraquara) - Endodontics Division - Hospital de Reabilitação de Anomalias Craniofaciais USP, Bauru, SP, Brazil.

3- DDS, PhD - Endodontics Division - Hospital de Reabilitação de Anomalias Craniofaciais - USP, Bauru, SP, Brazil.

Corresponding address: Carla Renata Sipert - Rua São Gonçalo 6-73, apto. 124, Bauru - SP - Brazil - Cep.: 17012-170 - e-mail: sipert@usp.br

Received: October 10, 2004 - Modification: June 07, 2005 - Accepted: August 29, 2005
\end{abstract}

\begin{abstract}
$I_{\text {n }}$

Introduction and objective: The aim of this study was to evaluate the ability of root canal cleaning of the RaCe rotary instrumentation system (FKG Dentaire - La-Cheaux-de Fonds - Switzerland), compared to manual filing with Stainless Steel Kfiles (Maillefer Instruments - Ballaigues - Switzerland). Material and Method: Twenty extracted human teeth (maxillary molars) were selected and their pulp tissue was removed after coronal access. The root canals were filled with a dye (India ink) and allowed to dry for 48 hours, followed by establishment of the working length of the mesiobuccal root; then, half of the specimens were instrumented by the modified Oregon technique and the other half were instrumented by crown-down sequence of the RaCe system. After preparation, the teeth were longitudinally sectioned and evaluated according to the amount of remaining dye. Results: Data obtained were registered as numerical scores, and the arithmetic means were compared between groups using the Mann Whitney test. Both techniques were unable to completely clean the interior of the root canals, with a better performance of the manual technique only at the middle third. Conclusion: It could be concluded that the RaCe system was able to provide satisfactory cleaning, similar to that obtained by the manual instrumentation technique.

Uniterms: Rotary instrument; Root canal preparation; Root canal cleaning.
\end{abstract}

\section{RESUMO}

objetivo deste trabalho foi avaliar a capacidade de limpeza de canais radiculares por meio do sistema de instrumentação RaCe (FKG Dentaire - La-Cheaux-de Fonds - Suíça) em comparação à instrumentação manual por meio de limas tipo K-File (Maillefer Instruments - Ballaigues - Suíça). Foram selecionados 20 dentes humanos extraídos (molares superiores) que tiveram seu conteúdo radicular removido após realização da abertura coronária. Os canais foram preenchidos com corante (tinta nanquim) e após 48 horas para secagem, realizou-se a odontometria da raiz mésio-vestibular. Metade dos espécimes foi instrumentada pela técnica de Oregon modificada e a outra metade pela seqüência crown-down preconizada pelo fabricante do sistema RaCe. Após o preparo, os dentes foram seccionados longitudinalmente e avaliados de acordo com a quantidade de corante remanescente. Os dados obtidos foram registrados por meio de escores numéricos e as médias aritméticas foram analisadas entre os grupos pelo teste de Mann Whitney. Ambas as técnicas foram incapazes de limpar completamente o interior dos canais radiculares sendo que a técnica manual desempenhou limpeza significantemente superior apenas no terço médio. Conclui-se que o sistema RaCe foi capaz de desempenhar uma limpeza satisfatória sendo próxima àquela conseguida pela técnica de instrumentação manual.

Unitermos: Endodontia, instrumentação; Instrumentos odontológicos; Cavidade da polpa dentária. 


\section{INTRODUCTION}

Successful root canal treatment depends, amongst other factors, on the removal of microorganisms by biomechanical instrumentation of the root canal system, including the infected dentin and organic tissue, by shaping and dissolution. Thus, the cleaning ability of a root canal instrument is of primordial importance for the outcome of endodontic treatment ${ }^{9}$. Other purpose of root canal filing is the achievement of a conical configuration, allowing a more effective filling ${ }^{16}$.

Enlargement of curved root canals with stainless steel (SS) files can many times result in instrumentation accidents such as transportation, ledge formation, perforation, tears and loss of working length ${ }^{18}$. Thus, nickel-titanium (NiTi) rotary instruments have been playing an important role in current endodontics, by allowing enough root canal preparation for filling with lower risk of accidents during instrumentation ${ }^{13}$.

The cleaning capacity of different NiTi rotary systems varies because of the different cross-sections and blade designs of each system ${ }^{12,13}$. A new design of cutting blades was recently introduced by the RaCe system (Reamer with Alternating Cutting Edges, FKG Dentaire, La-Chaux-deFonds, Switzerland ${ }^{6}$ ). These instruments have a triangular cross section with cutting edges that results in efficient removal of chips and debris. Moreover, these blades are alternated to eliminate the screwing on and blocking effects originated from continuous rotation and to reduce the working torque. This system also has a non-cutting safety tip as a secure method $^{6}$.

Little information is available in the literature on the cleaning ability of this new instrumentation system, specially compared to conventional manual filing. Thus, the purpose of this study was to compare the efficiency of instrumentation using the RaCe system with that provided by stainless steel K-Files by the modified Oregon technique.

\section{MATERIALS AND METHODS}

\section{Teeth selection and preparation}

Twenty extracted human maxillary molars presenting curved mesiobuccal roots were used in this study. The teeth were selected on the basis of a similar mesiobuccal curvature (25 - 30 degrees). Coronal access was achieved with diamond burs, and the root canals had their pulp tissue removed with Hedstroem Files (Maillefer Instruments - Ballaigues Switzerland) associated with $0.5 \%$ sodium hypochlorite irrigation. After this, additional irrigation was performed with $5 \mathrm{~mL}$ of distilled water, and the canals were air-dried. After drying, they were filled with India ink previously stored in anesthetic tubes, for insertion in the root canals with aid of a carpule syringe and a short gingival needle (BD - Rio de Janeiro - Brazil).

\section{Root canal instrumentation}

The dye was allowed to dry for 48 hours, and then the working length was obtained by initial measurement of an instrument (K-File \#10) introduced until the apical foramen and subtracting $1 \mathrm{~mm}$. Each series of instruments was utilized for preparation of four root canals and then disposed. After each change of instrument, the canal was irrigated with $1 \mathrm{~mL}$ of $1 \%$ sodium hypochlorite with a Luer-Lock syringe (Duflex - S.S. White Artigos Dentários LTDA - Rio de Janeiro Brazil), with introduction of the irrigation canula 30X4 (BDBecton Dickinson Indústrias Cirúrgicas LTDA - Rio de Janeiro - Brazil) until the maximum possible depth without inducing a pushing effect. Irrigation with sterile saline solution was performed at the end of instrumentation.

For root canal filing, the teeth were divided into two groups with 10 specimens each:

Group 1:

Manual instrumentation - this was conducted by the modified Oregon technique ${ }^{9}$ with stainless steel K-Files (Maillefer Instruments - Ballaigues - Switzerland). The apical limit was determined by a \#25 instrument, and step-back preparation was performed until \#40 instrument.

Group 2:

Rotary instrumentation - this was performed by utilization of the RaCe rotary system (FKG Dentaire - LaChaux-de-Fonds, Switzerland) employing the crown-down sequence (.10\#40, .08\#35, .06\#30,.04\#25, .02\#25), following the manufacturer's instructions with an Endo-Mate 2 motor (NSK Nakanishi Inc. - Tochigi - Japan), at a speed of approximately $300 \mathrm{rpm}$.

After instrumentation, the teeth were longitudinally sectioned with a carborundum disk (Dentorium International - NY - USA). The hemisections obtained were fixed in a paper leaf with adhesive tape with the root canal wall turned upwards. The canals were divided into three thirds (cervical, middle and apical) for individual evaluation. The canal cleaning was evaluated employing a magnifying glass Bestar (OTIMUS Warenvertriebs - Frankfurt Germany) with 4x magnification, and data were registered on the basis of dye removal by numerical scores (Figure 1). The arithmetic means of these values were statistically compared by the non-parametric Mann Whitney test, between both techniques tested, at each region of the sectioned teeth.

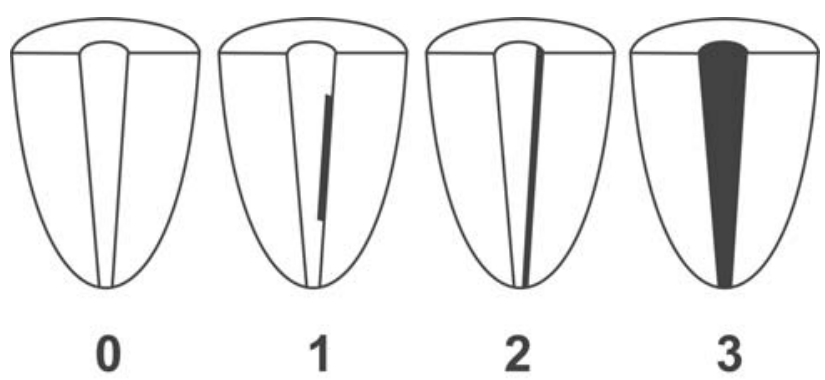

FIGURE 1- Scores of dye removal: 0 - no remaining dye; 1 - small area with dye in one of the root canal walls; 2 presence of dye throughout a root canal wall; 3 - presence of dye throughout the root canal (scores were utilized at each canal third individually) ${ }^{8}$ 


\section{RESULTS}

Data obtained by evaluation of dye removal are displayed in the following table 1. During instrumentation, none of the instruments, either manual or rotary, presented separation or any signal of deformation.

In general, manual instrumentation using stainless steel K-Files resulted in less amount of remaining dye compared to the group of rotary instrumentation. Statistically, however, this difference was significant only at the middle third $(\mathrm{P}=0.00893)$. For the cervical and apical thirds, the $\mathrm{P}$ values were 0.190316 and 0.315 , respectively.

\section{DISCUSSION}

One of the most important purposes of root canal instrumentation is the removal of vital or necrotic pulp tissue, infected dentin and dentin debris, with the objective to eliminate most microorganisms from the root canal system ${ }^{5}$. The success of endodontic therapy depends on the operator ability to develop shaping and cleaning of the root canals, which should be effective and safe $\mathrm{e}^{10}$. For effective attainment of these objectives, many systems and instrumentation techniques have been created for professional use; however, as in the case of the RaCe system, few studies have evaluated its performance in endodontic filing. Thus, the effectiveness of instrumentation of the root canal walls was evaluated in this study, comparing the RaCe system with a manual instrumentation technique (modified Oregon technique ${ }^{9}$ ).

The choice of human teeth for this evaluation, instead of simulated root canals in resin blocks, involves anatomic variability between the specimens, which impairs the achievement of identically shaped canals ${ }^{13}$. However, this parameter is the same found in the clinical situation, and thus investigations with these experimental conditions are warranted $^{1,8,14}$.

Analysis of the cleaning ability of some instrumentation systems by removal of the dye adhered to the root canal walls has been conducted in the literature by some authors such as Aragão and Garcia², Gonçalves, et al. ${ }^{8}$, Nishiyama and Garcia ${ }^{11}$. This technique is easy to perform, yet it does not allow differentiation between the areas of debris (dentin fragments and pulp remnants) and the smear layer (a film produced by action of the instrument), which is possible by utilization of scanning electron microscopy (SEM) $)^{1,12,14,15}$.

Considering the mechanical action of the instruments tested, the primary aim of this study and the cleaning ability of irrigating solutions, isolated utilization of $\mathrm{NaOCl}$ without addition of chelants was chosen, since the cleaning effect should be restricted to removal of instrumentation debris by the hydrodynamics of irrigation and dissolution of the organic remnants by the chemical action of this irrigating solution $^{14}$.

At the present investigation, neither separation nor signs of deformation were observed by utilization of either manual or rotary instruments. These data disagree with other studies, which mention the occurrence of this fenomenon ${ }^{12,14,15}$. Limitation of utilization of each instrument on four root canals, the rotation used for rotary filing (300 rpm), as well the gentle apical pressure employed, may have accounted for the absence of accidents even in remarkably curved root canals, as observed in some specimens ${ }^{6}$. This low incidence of fracture could either been related to the triangular cross-section of the RaCe system, with more shaped blades, and to the greater center area compared to U-shaped systems or systems with radial lands ${ }^{6,13}$.

The total dye removal from the interior of the root canals and consequent complete cleaning were not achieved by any of the instrumentation techniques, in agreement with previous studies ${ }^{1,3,12-15}$.

Comparing the efficacy of the RaCe system to SS KFlexofiles under SEM, Baumann, et al. ${ }^{4}$ observed better performance of the RaCe system either for canal shaping and smear layer removal. In an analysis of the efficiency of two rotary systems (RaCe and ProTaper) in simulated root canals, Schäfer and Vlassis ${ }^{13}$ found better maintenance of the original trajectory of the root canal, less apical transportation, less loss of working length and loss of operational time for the RaCe system. Schäfer and Vlassis ${ }^{14}$ investigated the same systems in extracted human teeth under SEM for observation of the cleaning and shaping ability of these instruments. The study showed that removal of debris was better for the RaCe system, while for the smear layer the difference was not significant. Maintenance of the original curvature of the root canal was again superior for the RaCe system. Thus, existing studies about this rotary instrumentation system confirm the relatively satisfactory cleaning ability observed in the present investigation.

Many studies report comparison of cleaning provided by rotary systems with that achieved by manual files. Comparing these instruments (Flex-R files) with three rotary systems (Lightspeed, McXIM and Profile), Short, et al. ${ }^{17}$ did not find significant differences related to dentin wear

TABLE 1- Arithmetic mean and median of the scores obtained by visual evaluation of the amount of remaining dye inside the root canals

\begin{tabular}{|c|c|c|c|c|c|c|}
\hline \multirow{2}{*}{$\begin{array}{l}\text { Area } \\
\text { Technique }\end{array}$} & \multicolumn{2}{|c|}{ Cervical } & \multicolumn{2}{|c|}{ Middle } & \multicolumn{2}{|c|}{ Apical } \\
\hline & Mean & Median & Mean & Median & Mean & Median \\
\hline Manual & 1.00 & 1.00 & *0.60 & 0.50 & 1.50 & 2.50 \\
\hline $\mathrm{RaCe}$ & 1.50 & 2.00 & *1.80 & 2.00 & 2.00 & 2.50 \\
\hline
\end{tabular}

${ }^{*} \mathrm{p}<0.05$ 
between the rotary systems, whereas the difference between them and Flex-R files was significant, with more wear for this last group. Schäfer and Zapke ${ }^{15}$ studied the ProFile system and observed lower cleaning efficacy of these instruments in comparison with K-Flexofiles. The ProFile system was also compared to manual files (classical technique) by Ahlquist, et al. ${ }^{1}$ who found better performance for the manual files only at the apical third. Superior cleaning of flattened root canals was also allowed by manual files with the crown-down technique, when compared to the ProFile system ${ }^{3}$. With regard to the K3 system, Schäfer and Schlingemann ${ }^{12}$ found that utilization of stainless steel instruments (K-Flexofiles) left less remnants than utilization of the rotary system. In the other hand, the study of Gonçalves, et al. ${ }^{8}$ on the GT rotary system compared to manual instrumentation with K-File and association of both techniques did not reveal statistically significant differences between any groups.

Considering that in combination with less wear of the dentin structure, the same authors mention better maintenance of the original root canal and less apical transportation by the rotary instrumentation technique ${ }^{1,3,7,12,15,17}$, these findings play an important role in the clinical situation, since the greater flexibility of NiTi files and their lower cutting ability yield minimal indiscriminate removal of dentin tissue during root canal instrumentation ${ }^{12,18}$. Analysis of the present results also reveals a significantly superior performance of stainless steel files at the middle third of the root canals. This difference can be related to the use of Gates Glidden burs by the modified Oregon technique, ${ }^{9}$ and this could be a useful procedure in association with the rotary instrumentation to compensate for its worse performance at the middle third.

\section{CONCLUSION}

Even though both techniques were unable to provide complete cleaning of the root canals, the RaCe rotary system showed a relatively satisfactory cleaning ability, which was similar to that yielded by manual stainless steel files.

\section{REFERENCES}

1 - Ahlquist M, Henningsson O, Hultenby K, Ohlin J. The effectiveness of manual and rotary techniques in the cleaning of root canals: a scanning electron microscopy study. Int Endod J. 2001;34(7):533-7.
5 - Consensus report of the European Society of Endodontology on quality guidelines for endodontic treatment. Int Endod J. 1994;27(3):115-24.

6 - FKG RaCe \& SMD. Rotary endodontic system. Suisse: FKG Dentaire; s.d.

7 - Glassmann GD, Serota KS. Endodontics in transition: evolution of the rotary revolution. Oral Health. 1997;87(10):37-40.

8 - Gonçalves SB, Brosco VH, Bramante CM. Análise comparativa entre instrumentação rotatória (GT), manual e associação de ambas no preparo de canais achatados. J Appl Oral Sci. 2003;11(1):35-9.

9 - Leonardo MR. Preparo biomecânico dos canais radiculares: definição, conceituação, finalidades, importância, recursos para sua aplicação e meios químicos. In: Leonardo MR, Leal JM. Endodontia: tratamento de canais radiculares. 3. ed. São Paulo: Panamericana; 1998. p. 333-5.

10 - Namazikhah MS, Mokhlis HR, Alasmakh K. Comparison between a hand stainless-steel K file and a rotary NiTi 0.04 taper. J Calif Dent Assoc. 2000;28(6):421-6.

11 - Nishiyama CK, Garcia RB. Estudo comparativo entre as técnicas de instrumentação escalonada regressiva, Oregon modificada, sistema canal finder e canal master "U" na limpeza de canais radixulares. Rev Odontol Univ São Paulo. 1993; 7(3):173-9.

12 - Schäfer E, Schlingemann R. Efficiency of rotary nickel-titanium K3 instruments compared with stainless steel hand K-Flexofile. Part 2. Cleaning effectiveness and shaping ability in severely curved root canals of extracted teeth. Int Endod J. 2003;36(3):208-17.

13 - Schäfer E, Vlassis M. Comparative investigation of two rotary nickel-titanium instruments: ProTaper versus RaCe. Part 1. Shaping ability in simulated curved canals. Int Endod J. 2004;37(4):229-38.

14 - Schäfer E, Vlassis M. Comparative investigation of two rotary nickel-titanium instruments: ProTaper versus RaCe. Part 2. Cleaning effectiveness and shaping ability in severely curved root canals of extracted teeth. Int Endod J. 2004;37(4):239-48.

15 - Schäfer E, Zapke K. A comparative scanning electron microscopic investigation of the efficacy of manual and automated instrumentation of root canals. J Endod. 2000;26(11):660-4.

16 - Schilder H. Canal debridement and disinfection. In: Cohen S, Burns RC, eds. Pathways of the pulp. Saint Louis: Mosby; 1976. p.111-33.

17 - Short JA, Morgan LA, Baumgartner JC. A comparison of canal centering ability of four instrumentation techniques. J Endod. 1997;23(8):503-7.

18 - Song YL, Bian Z, Fan B, Fan MW, Gutmann JL, Peng B. A comparison of instrument-centering ability within th root canal for three contemporary instrumentation techniques. Int Endod J. 2004;37(4):265-71.

2 - Aragão EM, Garcia RB. Análise comparativa das técnicas de instrumentação escalonada, Oregon modificada e ultra-sônica na remoção de corante aderido às paredes do canal radicular. Rev Odontol Univ São Paulo. 1994;8(3):211-5.

3 - Barbizam JV, Fariniuk LF, Marchesan MA, Pecora JD, Sousa-Neto MD. Effectiveness of manual and rotary instrumentation techniques for cleaning flattened root canals. J Endod. 2002;28(5):365-6.

4 - Baumann MA, Leinbrock O, Hellmich M, Baumann-Giedziella UA. Effectiveness of root canal instrumentation with RaCe: an SEM study. J Endod. 2003;29(4):286. 